\title{
Regeneration of Graft Livers and Limited Contribution of Extrahepatic Cells After Partial Liver Transplantation in Humans
}

\author{
Susumu Eguchi · Mitsuhisa Takatsuki • \\ Kosho Yamanouchi · Yukio Kamohara • \\ Yoshitsugu Tajima $\cdot$ Takashi Kanematsu
}

Received: 4 January 2009/Accepted: 23 February 2009/Published online: 19 March 2009

(c) The Author(s) 2009. This article is published with open access at Springerlink.com

\begin{abstract}
Background Liver regeneration is still not fully understood. Partial liver transplantation (LT) can provide the opportunity to investigate the mechanisms of liver regeneration, including the contribution of extrahepatic cells to liver regeneration. Methods Of 61 patients transplanted with partial liver graft between August 1997 and October 2006, 56 patients were studied, including 49 adults and 7 children. Sequential computed tomography volumetric analysis was performed for volume measurement, while proliferating cell nuclear antigen (PCNA) labeling index was investigated for liver cell proliferation in nonprotocol liver biopsy specimens. In addition, 15 male recipients who had female liver grafts were investigated in order to detect $\mathrm{Y}$ chromosomes as extrahepatic cells in nonprotocol liver biopsy specimens. Results Graft volume per standard liver volume was markedly increased after adult-to-adult living-donor (LD) LT. In pediatric transplants, there was no volume increase over time. PCNA labeling index was vigorous in adult-to-adult LDLT in the early period after LDLT. No Y chromosome was evident in hepatocytes from female-donor male-recipient grafts during or after liver regeneration. However, in the cases of failing grafts of this type, many Y-chromosome-positive cells were observed in the graft liver. The character of those cells was CD34(-), CK9(-), hepatocyte-specific antigen(-), and CD68(+/-). Conclusion In adult-to-adult LDLT, vigorous liver regeneration occurs in the graft liver, demonstrated by not only volumetric but cell kinetic analysis. Involvement of extrahepatic cells in normal liver regeneration seems limited.
\end{abstract}

S. Eguchi $(\bowtie) \cdot$ M. Takatsuki · K. Yamanouchi · Y. Kamohara ·

Y. Tajima · T. Kanematsu

Department of Surgery, Nagasaki University Graduate School

of Biomedical Sciences, 1-7-1 Sakamoto,

Nagasaki 852-8501, Japan

e-mail: sueguchi@net.nagasaki-u.ac.jp
Keywords Living-donor liver transplantation . Liver regeneration $\cdot$ Extrahepatic cells

\section{Introduction}

The mechanism of liver regeneration is still not fully understood. Although vigorous liver regeneration after living-donor liver transplantation (LDLT) has been reported by us and others [1-3], it has been assessed by imaging studies such as computed axial tomography (CAT) scan, not hepatocyte cell division. In the present study, we took the opportunity to use liver biopsy specimens to verify liver regeneration in partial liver recipients during various periods after LDLT.

In addition, during liver regeneration it has been reported that extrahepatic cells, especially bone marrow (BM)derived cells, are mobilized and involved [4-6]. However, details regarding how extrahepatic cells are involved and how much they contribute to normal liver regeneration have not been fully elucidated [7-10]. Therefore, we investigated liver biopsy specimens from female-donor male-recipient grafts, in which only XX cells should be present in the graft liver. We used fluorescent in situ hybridization (FISH) to detect $\mathrm{Y}$ chromosomes in the liver to identify extrahepatic cells in the liver upon liver regeneration.

\section{Materials and Methods}

Patients

Of 61 patients who underwent LDLT between August 1997 and October 2006 at Nagasaki University Hospital, 56 Japanese patients with survival times of more than 3 months 
were included for volumetric analysis. For adult recipients, right lobe grafts were transplanted in 40 recipients, while left-side grafts ( 8 extended left lobe graft, 1 left lobe graft) were performed in 9 recipients. Seven pediatric cases with left lateral lobe graft also underwent volumetric study. Adult patients were defined as those over 16 years old. When liver function test was deranged, total 93 liver biopsies were carried out, consisting of 83 in adult cases and 10 in pediatric cases, and were prepared for proliferative cell nuclear antigen (PCNA) staining. Within these, a total of 24 liver biopsies were performed in 15 recipients on indication from a pool of 19 male recipients (XY) who were transplanted with female livers (XX).

\section{Methods of LDLT}

All partial liver grafts were preserved in University of Wisconsin solution and implanted using a piggyback technique. In general, graft selection was based on the results of volumetric studies using CAT scans to obtain ratios of graft volume to standard liver volume of more than $35 \%$ in the recipients.

A dual or triple immunosuppressive regimen was used, which included tacrolimus or cyclosporine A, steroid, and mycophenolate mofetil. Patients with compromised renal function were given induction therapy with interleukin-2 antibodies. Biopsy-proven rejections were treated if clinical and laboratory signs mandated steroid bolus treatment. Steroid-resistant rejections were treated with OKT3.

\section{Investigation for Liver Regeneration}

Incremental growth of the liver in volume was measured by serial CAT scans using Flexi Trace software (Tree Star, Inc., U.S.A.) at $0,1-2$ weeks, and 3 months after LDLT [1]. In liver biopsy specimens, expression of PCNA (DACO, Carpinteria, CA) was analyzed for intrahepatic proliferation [11].

Four-micrometer liver sections were deparaffinized in xylene and hydrated in graded ethanol. After deparaffinization, rehydration, and heating in $95^{\circ} \mathrm{C}$ buffer, sections were incubated with each antibody and subsequently with Histofine Simple Stain MAX-PO (MULTI) (Nichirei, Japan). Incubation was performed overnight at $4^{\circ} \mathrm{C}$ and followed by a wash in three changes of phosphate buffered saline (PBS) for $5 \mathrm{~min}$. For all stainings, the reaction product was developed with the use of 3-diaminobenzidine tetrahydrochloride and $\mathrm{H}_{2} \mathrm{O}_{2}$. The sections were counterstained with Meyer hematoxylin-eosin.

For hepatocyte staining, the goat anti-human hepatocyte-specific antigen $\mathrm{Ab}(\mathrm{R} \& \mathrm{D}$ system, Minneapolis, MN), and 2nd Ab biotinylated rabbit anti-goat Ig (DAKO, Carpinteria, CA) were used. For the staining of CK7 (bile duct marker), CD68 (macrophage marker) and CD34 (hematopoietic cells) were used, respectively, according to the manufacturer's protocol.

\section{Fluorescent In Situ Hybridization (FISH)}

FISH was performed in our reference laboratory (SRL, Nagasaki, Japan). Sections from paraffin-embedded biopsied liver tissues were placed on silane-coated glass slides. The slides were deparaffinized immediately in two rinses of $1,000 \mathrm{~g} / \mathrm{l}$ xylene for $10 \mathrm{~min}$ each. Each slide was rehydrated in an ethanol series for $5 \mathrm{~min}$. The slides were then treated with $0.2 \mathrm{~mol} / 1 \mathrm{HCl}$ for $20 \mathrm{~min}$, followed by $2 \times \mathrm{SSC}(0.3 \mathrm{~mol} / \mathrm{l}$ sodium chloride and $0.03 \mathrm{~mol} / \mathrm{l}$ sodium citrate) for $20 \mathrm{~min}$ at $80^{\circ} \mathrm{C}$, treated with $0.05 \mathrm{mg} /$ $\mathrm{ml}$ proteinase $\mathrm{K}$ in TEN $[0.05 \mathrm{~mol} / \mathrm{l}$ Tris- $\mathrm{HCl}, \mathrm{pH} 7.8$, $0.01 \mathrm{~mol} / 1$ ethylenediamine tetraacetic acid (EDTA), and $0.01 \mathrm{~mol} / \mathrm{l}$ sodium chloride] for $10 \mathrm{~min}$ at $37^{\circ} \mathrm{C}$, and placed in $40 \mathrm{~g} / \mathrm{l}$ formaldehyde in PBS for $10 \mathrm{~min}$. Both FISH probes and target DNA were denatured simultaneously for $10 \mathrm{~min}$ at $90^{\circ} \mathrm{C}$, and the slides were incubated overnight at $42^{\circ} \mathrm{C}$, placed in $2 \times \mathrm{SSC}$ for $10 \mathrm{~min}$ at $42^{\circ} \mathrm{C}$, washed twice in $2 \times \mathrm{SSC} / 500 \mathrm{~g} / 1$ formaldehyde formamide for $5 \mathrm{~min}$ each at $42^{\circ} \mathrm{C}$, washed $2 \times \mathrm{SSC}$ for $5 \mathrm{~min}$ at $42^{\circ} \mathrm{C}$, and counterstained in $2 \times \mathrm{SSC} / 0.03 \mu \mathrm{g} / \mathrm{ml} \mathrm{4',6-diamidino-2-}$ phenylindole (DAPI).

\section{Statistical Analysis}

For the data, Mann-Whitney $U$ test was used. Differences were considered statistically significant for $P$-value less than 0.05 .

\section{Results}

\section{Liver Volume}

Graft volume per standard liver volume at $0,1,3$, and 6 months after adult-to-adult LDLT was 53.2\%, 95.9\%, $98.5 \%$, and $101.2 \%$ in right lobe grafts and $41.1 \%, 81.9 \%$, $92.7 \%$, and $102.4 \%$ in left-sided grafts, respectively (Fig. 1). Since volume changes in pediatric LDLT were not evident, they are not included in the figure.

DNA Synthesis in the Liver

PCNA labeling index was vigorous in adult-to-adult LDLT in the early period after LDLT, while it was not evident in pediatric LDLT (Fig. 2). 


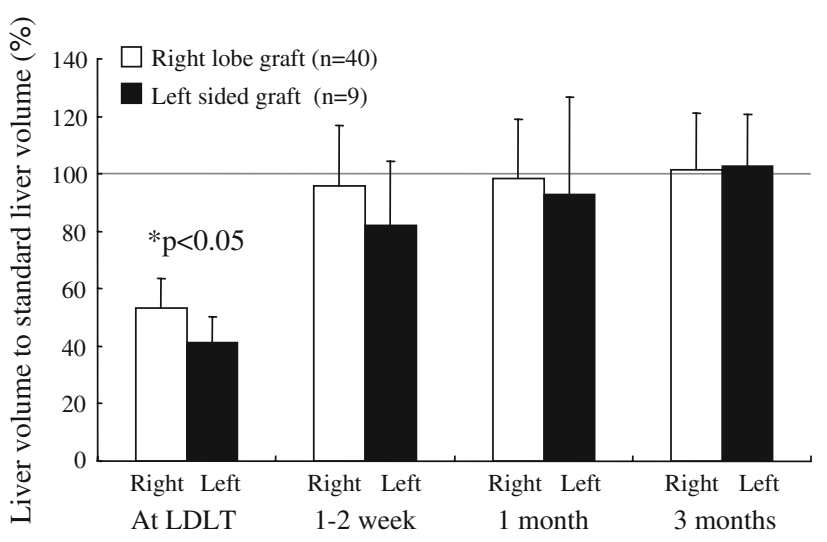

Time after LDLT

Fig. 1 Liver regeneration of right lobe or left lobe graft liver after adult-to-adult LDLT using volumetric analysis using CAT scan. $L D L T$ living-donor liver transplantation, $C A T$ computed axial tomography

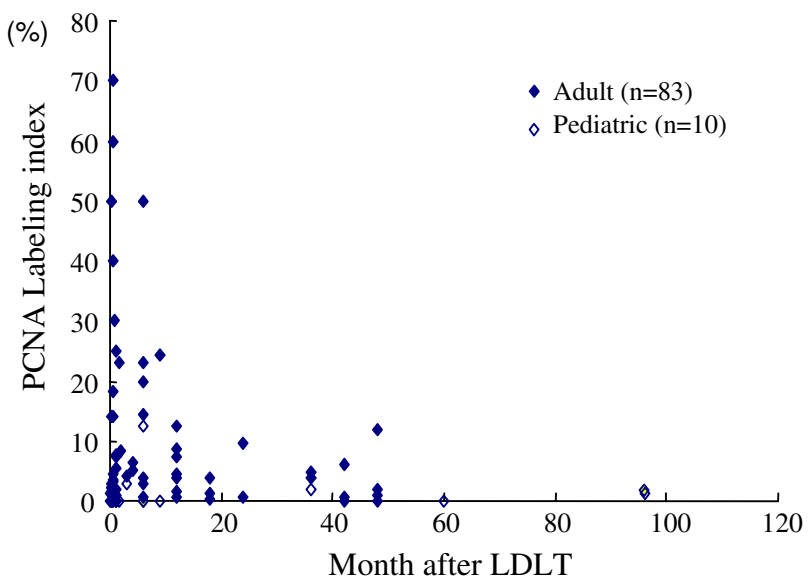

Fig. 2 PCNA labeling index after LDLT using immunohistochemical staining. $P C N A$ proliferating cell nuclear antigen, $L D L T$ living-donor liver transplantation

FISH and Immunohistochemical Staining for Y-Positive Cells

Y chromosome was not evident in hepatocytes of femaledonor male-recipient grafts after normal liver regeneration in adult-to-adult LDLT recipients (Fig. 3, case 1). As seen in this case, when graft livers did not receive any damage and underwent normal liver regeneration, existence of $\mathrm{Y}$ chromosome-positive cells was limited with FISH examination. However, in the case of failing graft, such as in cases 11-13, many Y-chromosome-positive cells were observed in zone 1 of the graft liver (Fig. 3, case 11).

For these cases, immunohistochemical staining was performed in the area with Y chromosomes. CD34(-), CK9(-), hepatocyte $\operatorname{Ag}(-)$, and CD68(+/-) were observed using immunohistochemical staining (Fig. 4, case 11). In the case of chronic liver damage (Fig. 5, case 15) after LDLT due to biliary complication, a few Y-positive cells were also detected with nonspecific staining for CD34, CK9, hepatocyte Ag, and CD68. Results of immunohistochemical staining are summarized in Tables 1 and 2.

\section{Discussion}

In this report, we showed liver regenerative response after partial LT using not only volumetric CAT scan study but also PCNA labeling of biopsy specimens. Previously, we reported vigorous liver regenerative response after partial liver regeneration and investigated liver regenerative growth factors after liver regeneration [11]. Herein, we showed a clear difference in proliferation of graft liver according to recipient body size and blood flow due to the difference in responses when transplanted in adults and children with different standard liver volumes. We did not carry out statistical analysis on PCNA index since it exhibited wide deviation. Liver regeneration remains an unsolved phenomenon, but our results show that it could be related to factors in recipients, as we reported previously [1]. Since protocol biopsy tends to be avoided because of risk of hemorrhage etc., further investigation is needed to assess cell proliferation noninvasively aside from CAT scan. Also since liver biopsy was not done on protocol, rejection or inflammation could have affected the data of PCNA staining. Although it would be interesting to investigate the difference in liver regeneration between patients after liver resection and those after partial liver transplantation, biopsy specimen from patients after liver resection cannot be obtained because of risk of complications. Therefore this also remains for further investigation. Our liver specimens from liver transplant recipients were obtained because of on-demand liver biopsy.

In addition, for combinations of female donor (XX) and male recipient $(\mathrm{XY})$, the $\mathrm{Y}$ chromosome was investigated in the biopsy specimen of the female liver (XX) in order to investigate the contribution of extrahepatic cells to liver regeneration. Previously, in an in vivo experiment conducted in 2000, it was reported that hepatocytes could be derived from BM cells [12]. Subsequently, in 2001, Baccarani et al. [13] reported that, in human recipients, replacement of a female liver venous endothelium with male BM showed the possibility of involvement of BM cells in liver rearrangement. Fujii et al. [4] reported that BM cells participated in liver regeneration after hepatectomy, whereas the majority of cells were committed to sinusoidal endothelial cells. Very recently, Conzelmann et al. [5], using their reduced-size LT model, reported that recipient-derived progenitor cells were present and might contribute to liver regeneration in mice. However, in 2005 Di Campli et al. [7] reported no evidence of hematopoietic 
Fig. 3 FISH for Y chromosome in liver biopsy specimens. Case 1 showed normal liver regeneration after LDLT. a At the time of LDLT, few Ychromosome-positive cells were seen. b With time, although GV/ SLV increased, a few Ychromosome-positive cells were seen only in the sinusoid. c Case 11 had severe acute rejection at 1 week after LDLT. d In the biopsy specimen, massive accumulation of Y-chromosome-positive cells was seen, mimicking hepatic structure. FISH fluorescent in situ hybridization, $G V / S L V$ graft volume versus standard liver volume ratio
Case 1: normal liver regeneration
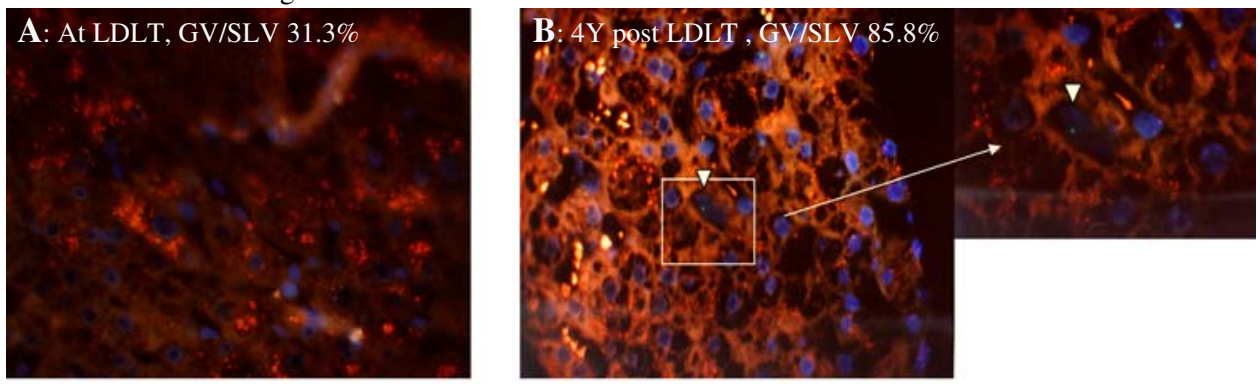

Case 11: acute cellular rejection - graft failure
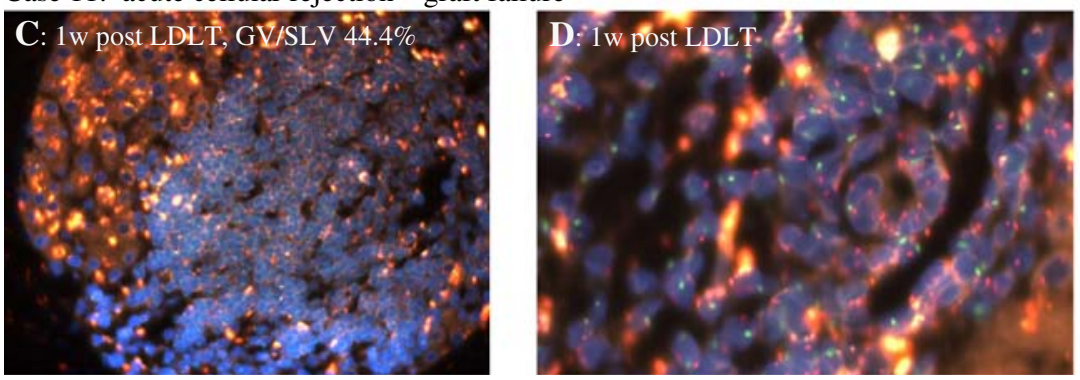
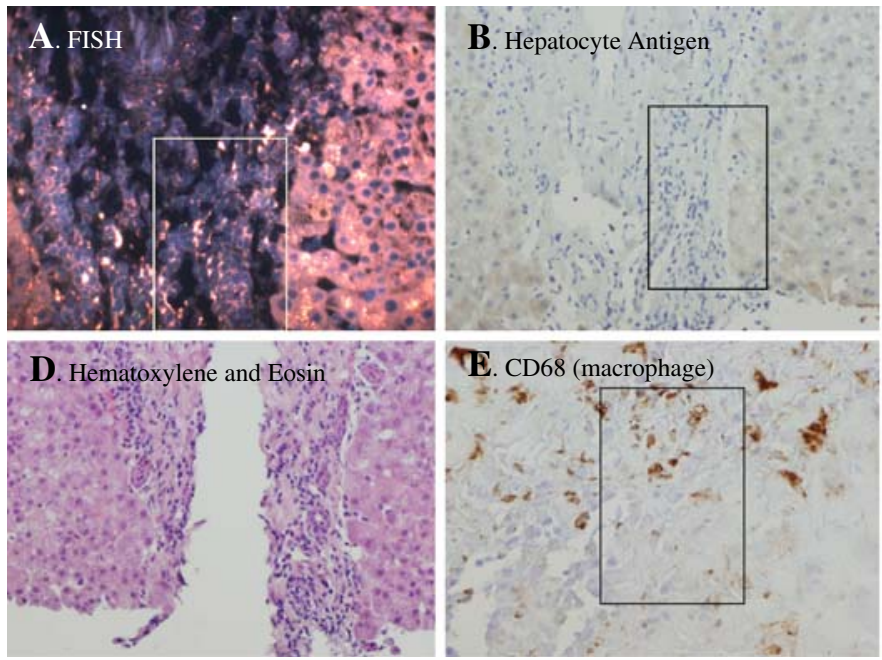

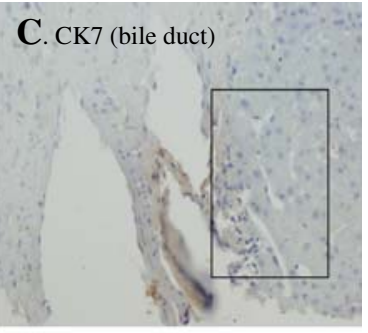

F. CD34 (hematopoietic)

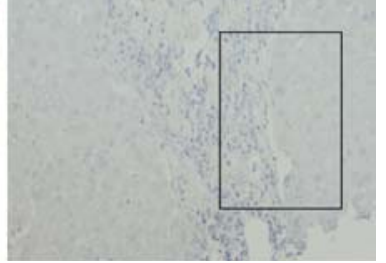

Fig. 4 Immunohistochemical stainings in case 11. Characterization of Y-chromosome-positive cells was attempted in corresponding area. a FISH showing Y-chromosome-positive cells (white square), b hepatocyte antigen was not positive in the black square, c CK7

stem cell mobilization in patients who underwent hepatectomy or in patients with acute liver failure. Similarly, in 2006, Moritoki et al. [8], using green fluorescent protein transgenic mice, demonstrated that $\mathrm{BM}$ cell transfer seemed not to contribute to the differentiation of cholangiocytes in a chronic cholestasis model. In 2007, Tomiyama [6] reported the limited contribution of cells originating from intact extrahepatic tissue in hepatocyte regeneration in transplanted rat livers. Thus, it is still unknown whether extrahepatic cells such as BM cells could contribute to liver regeneration or liver repair, especially in humans. (cytokeratin 7, bile duct) was not positive in the black square, d hematoxylin and eosin staining, e CD68 (macrophage) was partially positive in the black square, f CD34 (hematopoietic cell) was not positive in the black square

In our study, we did not find many Y-chromosomepositive cells after liver transplantation with normal liver regeneration. If extrahepatic cells had been involved and integrated into normal liver regeneration, they should have stayed and been found in the liver biopsied a long time after LDLT. This is indirect evidence that would seem to rule out extrahepatic cell contribution to normal liver regeneration in humans, in contrast to previous reports [12, 13]. On the other hand, when failing livers were biopsied, many Y-chromosome-positive cells were present. Although we could not clearly show the origin of those Y-positive cells, circulating macrophages were candidate sources 
Fig. 5 Immunohistochemical stainings in case 15 , secondary biliary cirrhosis after LDLT. a FISH showing Y-chromosomepositive cells (white square), b Azan staining was positive, showing the presence of liver fibrosis, c CK7 (cytokeratin 7, bile duct) was not positive in the black square, d CD68 (macrophage) was partially positive in the black square, e CD34 (hematopoietic cell) was not positive in the black square. $L D L T$ living-donor liver transplantation
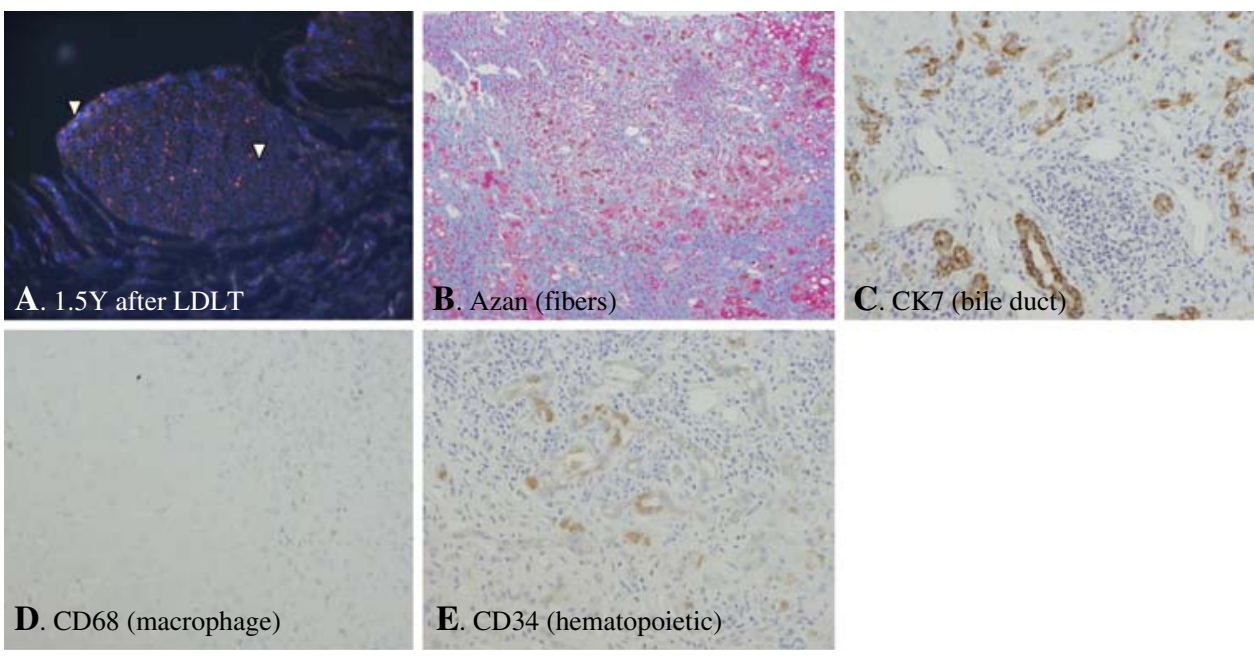

Table 1 Demographics of male recipients with female donors

\begin{tabular}{|c|c|c|c|c|c|c|c|c|c|}
\hline Case no. & Age & Gender & Etiology & Donor & Blood type match & Graph type & Biopsy period after LDLT & Comments & Outcome \\
\hline 1 & 16 & M & FHF & Mother & Identical & $\mathrm{L}$ & $3 d, 4 Y$ & None & Survived \\
\hline 2 & 5 & M & BA & Mother & Identical & LL & $2 \mathrm{M}, 8 \mathrm{Y}$ & Cholestasis & Survived \\
\hline 3 & 56 & M & LC-B/HCC & Sister & Identical & $\mathrm{R}$ & $1.5 \mathrm{M}, 1.8 \mathrm{Y}, 2 \mathrm{Y}$ mild ACR & None & Survived \\
\hline 4 & 20 & M & FHF & Aunt & Identical & $\mathrm{R}$ & $1 \mathrm{M}, 5 \mathrm{M}, 2 \mathrm{Y}$ & Cholestasis & Survived \\
\hline 5 & 58 & M & LC-C & Sister & Identical & $\mathrm{R}$ & $2 \mathrm{M}$ & Hepatitis & Survived \\
\hline 6 & 56 & M & $\mathrm{LC}-\mathrm{B} / \mathrm{HCC}$ & Daughter & Identical & $\mathrm{R}$ & $8 \mathrm{M}$ & Vanishing BD & Survived \\
\hline 7 & 56 & M & LC-B/HCC & Daughter & Identical & $\mathrm{R}$ & 9M (Re-LDLT) & Poor quality & Survived \\
\hline 8 & 56 & M & LC-B/HCC & Wife & Identical & $\mathrm{R}$ & $6 \mathrm{M}$ & Mild ACR & Survived \\
\hline 9 & 58 & M & $\mathrm{LC}-\mathrm{C} / \mathrm{HCC}$ & Daughter & Incompatible & $\mathrm{R}$ & $3 \mathrm{~W}$ & Hepatitis & Survived \\
\hline 10 & 62 & M & LC-C & Sister & Compatible & $\mathrm{L}$ & $1.5 \mathrm{M}$ & Moderate ACR & Survived \\
\hline 11 & 41 & M & PBC & Wife & Identical & $\mathrm{R}$ & $1 \mathrm{~W}, 1 \mathrm{M}$ (autopsy) & Severe ACR & Died $(2 \mathrm{M})$ \\
\hline 12 & 50 & M & LC-B & Wife & Identical & $\mathrm{R}$ & 10d (graft failure) & Malcirculation & Died $(1 \mathrm{M})$ \\
\hline 13 & 57 & M & $\mathrm{LC}-\mathrm{C} / \mathrm{HCC}$ & Wife & Identical & $\mathrm{R}$ & 10d, $2 \mathrm{M}$ (graft failure) & Moderate ACR & Died $(2 \mathrm{M})$ \\
\hline 14 & 47 & M & LC-Al & Sister & Identical & $\mathrm{R}$ & 3.8Y (liver cirrhosis) & Poor quality & Died $(3.8 \mathrm{Y})$ \\
\hline 15 & 51 & M & LC-C & Sister & Identical & $\mathrm{R}$ & $2.5 \mathrm{Y}$ (chronic liver failure) & Biliary cirrhosis & Died $(2.5 \mathrm{Y})$ \\
\hline
\end{tabular}

$F H F$ fulminant hepatic failure, $B A$ biliary atrasia, $A C R$ acute cellular rejection, $L C$ - $B$ liver cirrhosis due to hepatitis $\mathrm{B}, L C$ - $C$ liver cirrhosis due to hepatitis C, $L C$ - $A l$ liver cirrhosis due to alcohol hepatitis, $H C C$ hepatocellular carcinoma, $P B C$ primary biliary cirrhosis, $d$ days, $M$ months, $Y$ years, $L D L T$ living-donor liver transplantation

Table 2 Summary of results

\begin{tabular}{llll}
\hline & $\begin{array}{l}\text { Normal } \\
\text { regeneration }\end{array}$ & $\begin{array}{l}\text { Acute graft } \\
\text { failure }\end{array}$ & $\begin{array}{l}\text { Chronic graft } \\
\text { failure }\end{array}$ \\
\hline Y chromosome & - & ++ & + \\
Hepatocyte antigen & - & - & - \\
CK7 (bile duct) & - & - & - \\
CD68 (macrophage) & - & Partial + & - \\
CD34 (hematopoietic) & - & + & + \\
\hline
\end{tabular}

because some cells were positive for CD68, which we used to identify macrophages. However, CD34, used for hematopoietic cells, was negative, which indicated that those
Y-positive cells did not have hematopoietic origins. In addition, there may be significant sampling variability in liver biopsy specimens from a single liver biopsy, which may not necessarily be representative of the entire liver. In liver chronically damaged by biliary complication, Y-chromosome-positive cells were not as numerous as seen in the case of acute graft failure. In addition, despite the information about expression of progenitor cell markers such as c-kit and Thy-1, we did not investigate this in this study; this awaits further investigation. With regard to CD68(+) Y chromosome(+) cells, we presume that they are regular macrophages from recipient side to dispose of damaged cells in failing liver, not special multipotent stem cells expressing CD68. 
In conclusion, in adult-to-adult LDLT, vigorous liver regeneration occurs in graft livers. Involvement of extrahepatic cells in normal adult-to-adult liver regeneration seems limited.

Open Access This article is distributed under the terms of the Creative Commons Attribution Noncommercial License which permits any noncommercial use, distribution, and reproduction in any medium, provided the original author(s) and source are credited.

\section{References}

1. Eguchi S, Yanaga K, Sugiyama N, Okudaira S, Furui J, Kanematsu T. Relationship between portal venous flow and liver regeneration in patients after living donor right-lobe liver transplantation. Liver Transpl. 2003;9:547-551. doi:10.1053/j1ts.2003. 50128.

2. Akamatsu N, Sugawara Y, Kaneko J, et al. Effects of middle hepatic vein reconstruction on right liver graft regeneration. Transplantation. 2003;76:832-837. doi:10.1097/01.TP.0000085 080.37235.81.

3. Marcos A, Fisher RA, Ham JM, et al. Liver regeneration and function in donor and recipient after right lobe adult to adult living donor liver transplantation. Transplantation. 2000;69: 1375-1379. doi:10.1097/00007890-200004150-00028.

4. Fujii H, Hirose T, Oe S, et al. Contribution of bone marrow cells to liver regeneration after partial hepatectomy in mice. J Hepatol. 2002;36:653-659. doi:10.1016/S0168-8278(02)00043-0.

5. Conzelmann LO, Hines IN, Kremer M, Perry AW, Lemasters JJ, Wheeler MD. Extrahepatic cells contribute to the progenitor/stem cell response following reduced-size liver transplantation in mice. Exp Biol Med (Maywood). 2007;232:571-580.

6. Tomiyama K, Miyazaki M, Nukui M, et al. Contribution of cells of intact extrahepatic tissue origin to hepatocyte regeneration in transplanted rat liver. Transplantation. 2007;83:624-630. doi: 10.1097/01.tp.0000253942.16061.d9.

7. Di Campli C, Piscaglia AC, Giuliante F, et al. No evidence of hematopoietic stem cell mobilization in patients submitted to hepatectomy or in patients with acute on chronic liver failure. Transplant Proc. 2005;37:2563-2566. doi:10.1016/j.transproceed. 2005.06.072.

8. Moritoki Y, Ueno Y, Kanno N, et al. Lack of evidence that before marrow cells contribute to cholangiocyte repopulation during experimental cholestatic ductal hyperplasia. Liver Int. 2006;26: 457-466. doi:10.1111/j.1478-3231.2006.01250.x.

9. am Esch JS 2nd, Knoefel WT, Klein M, et al. Portal application of autologous CD133+ bone marrow cells to the liver: a novel concept to support hepatic regeneration. Stem Cells. 2005;23:463-470.

10. Ferry N, Hadchouel M. Liver regeneration: with a little help from marrow. J Hepatol. 2002;36:695-697. doi:10.1016/S0168-8278 (02)00054-5.

11. Eguchi S, Okudaira S, Azuma T, et al. Changes in liver regenerative factors in a case of living-related liver transplantation. Clin Transplant. 1999;13:536-544. doi:10.1034/j.1399-0012.1999. 130616.x.

12. Theise ND, Badve S, Saxena R, et al. Derivation of hepatocytes from bone marrow cells in mice after radiation-induced myeloablation. Hepatology. 2000;31:235-240. doi:10.1002/hep. 510310135.

13. Baccarani U, Donini A, Risaliti A, Bresadola F. Replacement of liver venous endothelium. Lancet. 2001;357:2137. doi:10.1016/S01406736(00)05209-0. 